\title{
Potential Utilization of Solid Waste (Bagasse Ash)
}

\author{
V. S. Aigbodion*, S. B. Hassan, T. Ause and G.B. Nyior \\ Department of Metallurgical and Materials Engineering, \\ Ahmadu Bello University, Samaru, Zaria, Nigeria. \\ *Corresponding Author: aigbodionv@yahoo.com
}

\begin{abstract}
Utilization of industrial and agricultural waste products in the industry has been the focus of research for economical, environmental, and technical reasons. Sugar-cane bagasse is a fibrous waste-product of the sugar refining industry, along with ethanol vapor. This waste-product is already causing serious environmental pollution which calls for urgent ways of handling the waste. In this paper, Bagasse ash has been chemically and physically characterized, in order to evaluate the possibility of their use in the industry. X-ray diffractometry determination of composition and presence of crystalline material, scanning electron microscopy/EDAX examination of morphology of particles, as well as physical properties and refractoriness of bagasse ash has been studied.
\end{abstract}

Key Words: Density; microstructure; particle size; refractoriness

\section{INTRODUCTION}

Researches all over the world today are focusing on ways of utilizing either industrial or agricultural wastes as a source of raw materials for the industry. These wastes utilization would not only be economical, but may also result to foreign exchange earning and environmental pollution control [1-3].

Bagasse is the matted cellulose fiber residue from sugar cane that has been processed in a Sugar mill. Previously, bagasse was burnt as a means of solid waste disposal. However, as the cost of fuel oil, natural gas, and electricity has increased, bagasse has come to be regarded as a fuel rather than refuse in the sugar mills $[4,5]$. 
Ganesan et al [6] stated that 1 ton of sugarcane generates $280 \mathrm{~kg}$ of bagasse, and that based on economics as well as environmental related issues, enormous efforts have been directed worldwide towards bagasse management issues i.e. of utilization, storage and disposal. Different avenues of bagasse utilization are more or less known but none of them have so far proved to be economically viable or commercially feasible [5, 7]. Hence the objective of this present work is to characterize the bagasse in order to explore it use in the metallurgical and materials industry.

\section{MATERIALS AND METHOD}

\subsection{Materials}

The bagasse used in this work was obtained from Zongo area of Zaria in Kaduna State of Nigeria. Other materials used are: Arabic gum and cotton wool. The photograph of the bagasse is shown in plate $1[5]$.

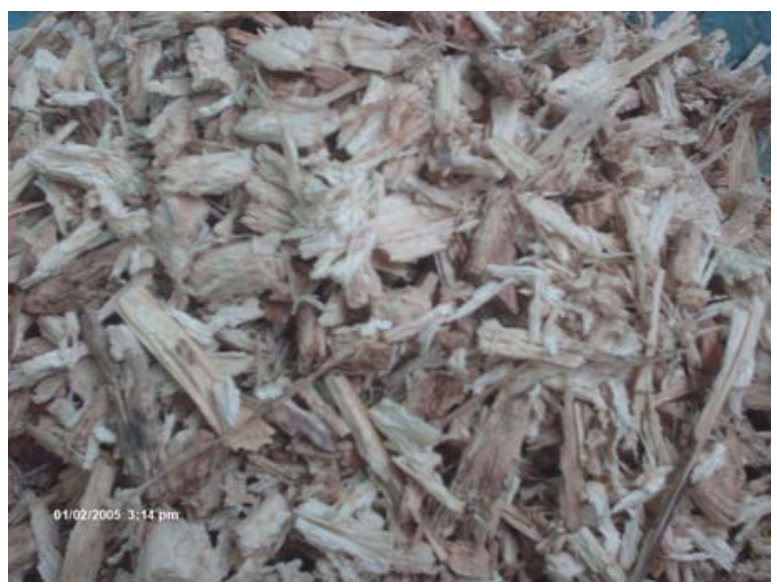

Plate 1: Photograph of the Bagasse

\subsection{Equipment}

Equipment used in this research are: Meter balance, Crucible, tong, Thermometer, Drying oven, Density bottles, Hydraulic press, Mixer, Hood type furnace, Steel mould and set of sieve, scanning electron microscopy (SEM) and X-ray diffractometry (XRD) machine.

\subsection{Methods}

\subsubsection{Bagasse carbonization}

The bagasse was packed in the graphite crucible air tight, and place inside electric control furnace and burnt at a temperature of $1200^{\circ} \mathrm{C}$ for 5 hours to obtain a black color ash (see plate 2) which is the bagasse ash which was used in this research [5]. 


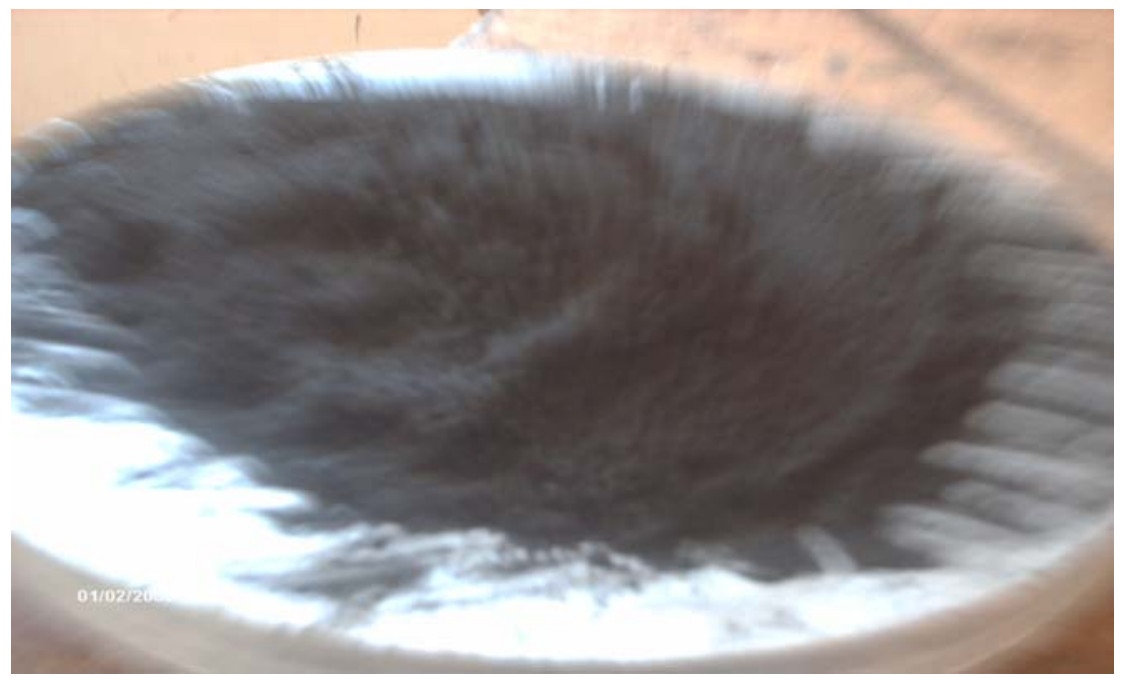

Plate 2: Photograph of the Bagasse after carbonization

\subsubsection{Particles size analysis}

The particle size distributions of the Bagasse ash were determined using the (AFS) specifications. $100 \mathrm{~g}$ each of the dried ash was taken and introduced unto a set of sieves arranged in descending order of fineness and shaken for 15 minutes which is the recommended shaking time to achieve complete classification. The weight retained on each sieve was taken and expressed as percentages of the total sample weight. From the weight retained, the grain fineness number (AFS) was computed [5].

\subsubsection{Chemical analysis and microstructure of the Bagasse ash}

The X-ray diffraction patterns of the ash sample derived from the bagasse was determine by Xray diffraction analysis which was carried out with a Siemens D-500 diffractometer using Co$\mathrm{K}_{\mathrm{c}}$ radiation $\left(\mathrm{K}_{\mathrm{c}}=1.79026 \mathrm{~A}\right)$. The microscopic study of the ash were determined by JEOL JSM840A scanning electron microscope (SEM) complemented by EDAX [5].

\subsubsection{Production of the test sample}

The ash was mixed thoroughly with Arabic gum and water to enhance plasticity. The mixed blend was each packed into a mould box and pressed using hydraulic jack. A pressure of about $9 \mathrm{~kg} / \mathrm{cm}^{2}$ was applied to enhance excellent mouldability, homogeneity and surface smoothness of the samples [5].

The moulded samples were dried in an open air for $24 \mathrm{hrs}$ at $110^{\circ} \mathrm{C}$ to expel any moisture and to avoid crack during firing. The dried bricks were then fired in an automatic digital electric furnace (Hood-type furnace) at a preset heating rate of $7^{\circ} \mathrm{C} / \mathrm{min}$ at different temperatures shown below; 
$200^{\circ} \mathrm{C}$ for 6hours, $650^{\circ} \mathrm{C}$ for 4 hours, $950^{\circ} \mathrm{C}$ for 3 hours, $1100^{\circ} \mathrm{C}$ for 8 hours and $1400^{\circ} \mathrm{C}$ for 8hours. After firing, the samples were allowed to cool in the furnace at a cooling rate of $1{ }^{\circ} \mathrm{C} / \mathrm{min}$ $[4,5]$. The sample was then removed from the furnace for physical test (see Plate 3 )

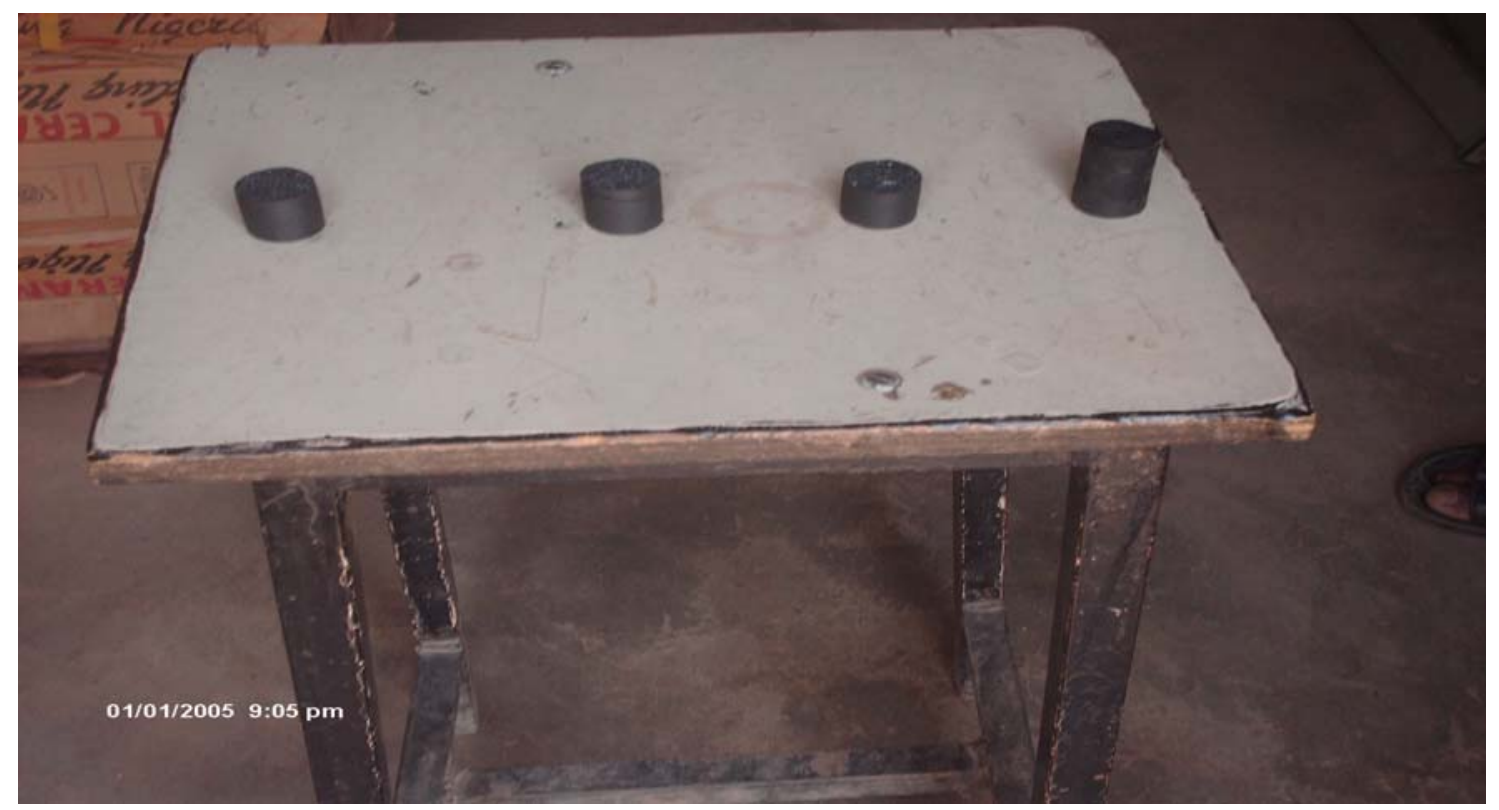

Plate 3: Photograph of the moulded Bagasse ash after firing

\subsubsection{Firing shrinkage}

The green weight of the sample was taken after moulding; and weight after firing was taken. The diagonal line across the sample in the green state and fired state were measured using the vernier caliper. The firing shrinkage was then calculated as a percentage of the original wet length as shown below [5, 7];

$\%$ of fired shrinkage $=\frac{L_{B^{2}}-L_{D}}{L_{E^{\prime}}} \times 100(\%)$

Where, $\mathrm{L}_{\mathrm{B}}=$ Dimension of green sample,$\quad \mathrm{L}_{\mathrm{D}}=$ Dimension of fired sample.

\subsubsection{Density}

The density of the respective samples was determined basically by measuring the mass and the volume by using the beam balance and the measuring cylinder respectively. It is then estimated from the formula given below [5-8].

$$
\text { Density }\left(\mathrm{g} / \mathrm{cm}^{3}\right)=\frac{\text { Mass }(\mathrm{g})}{\operatorname{Volume}\left(\mathrm{cm}^{3}\right)}
$$




\subsubsection{Refractoriness}

The Pyrometric Cone Equivalent (PCE) as recommended by ASTM Test C-24 was used in the determination of the refractoriness of the sample [5-7].

\section{RESULTS AND DISCUSSION}

\subsection{Particle Size}

Figure 1 shows the particle size distribution of the sample. The sample has a Grain Fineness Number (GFN) of 85.07, and based on this value, the sample can be considered to be fine as GFN value of 100 is ranked the finest.

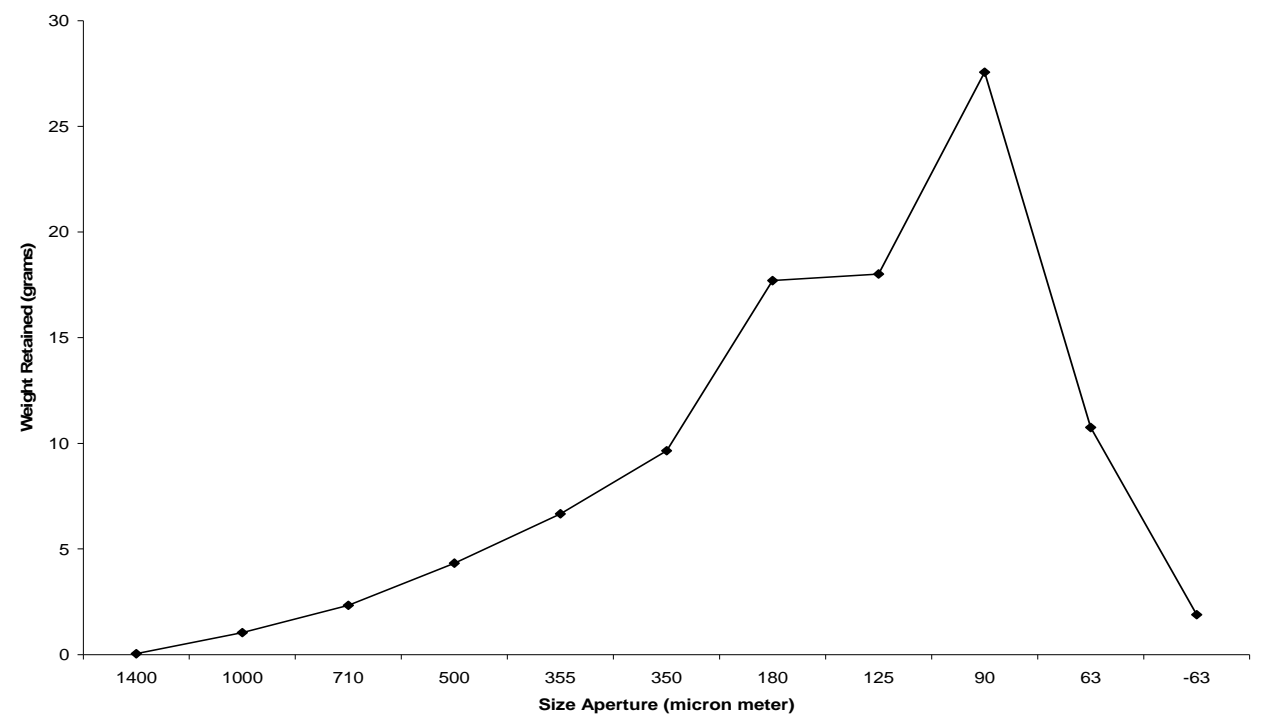

Figure 1: Particle size analysis of the Bagasse ash

Also, the sample can be considered to have met the AFS specification since four sieve-size, has the bulk of the retained sample on four consecutive sieves corresponding to $250 \mu \mathrm{m}, 180 \mu \mathrm{m}$, $125 \mu \mathrm{m}$, and $90 \mu \mathrm{m}$ size fractions (see Figure 1) respectively [5].

\subsection{Morphology}

The results of the X-ray diffractogram technique is presented in Figures 2-3, and Tables 1-2. 


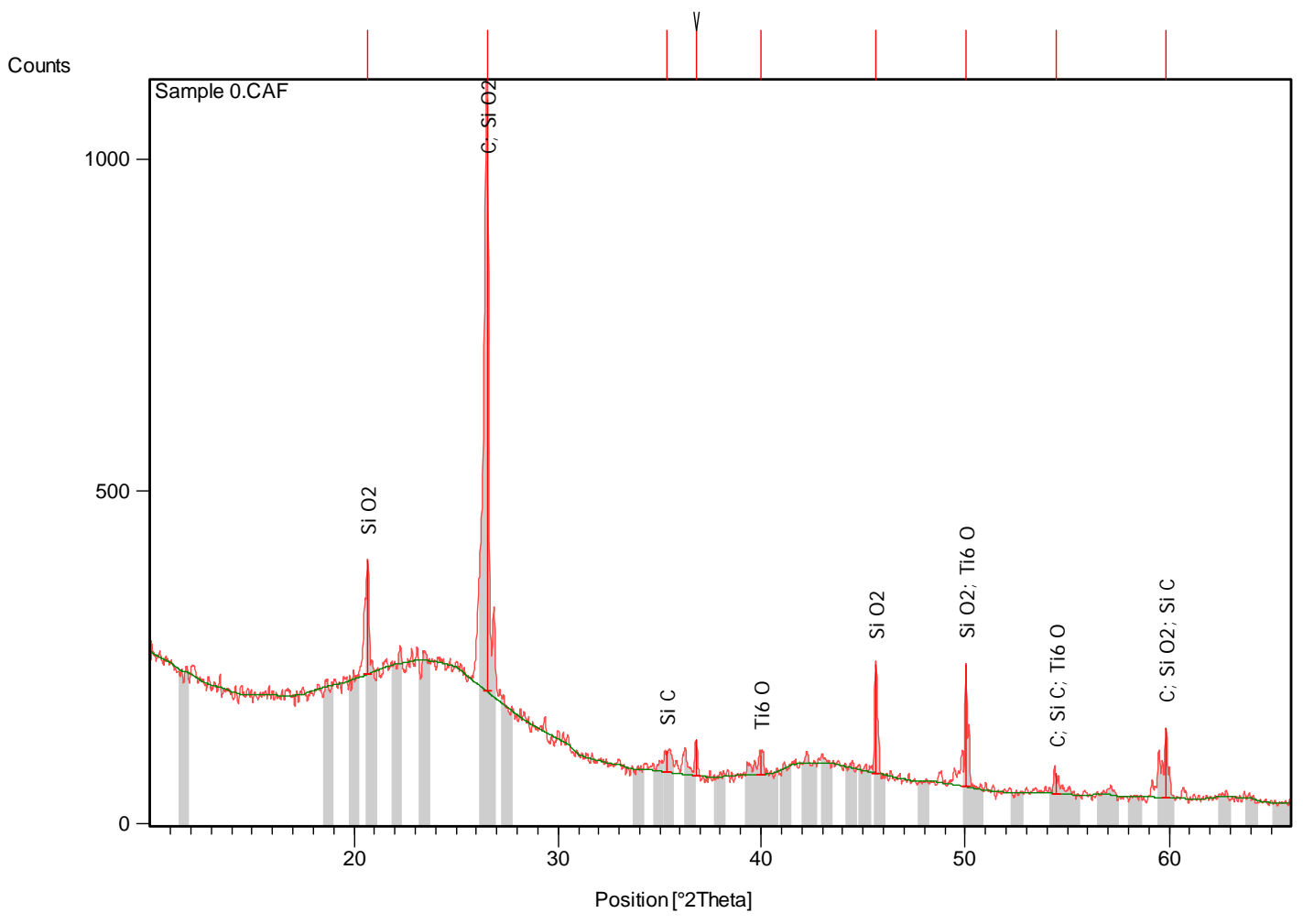

Figure 2: XRD pattern of the Bagasse ash

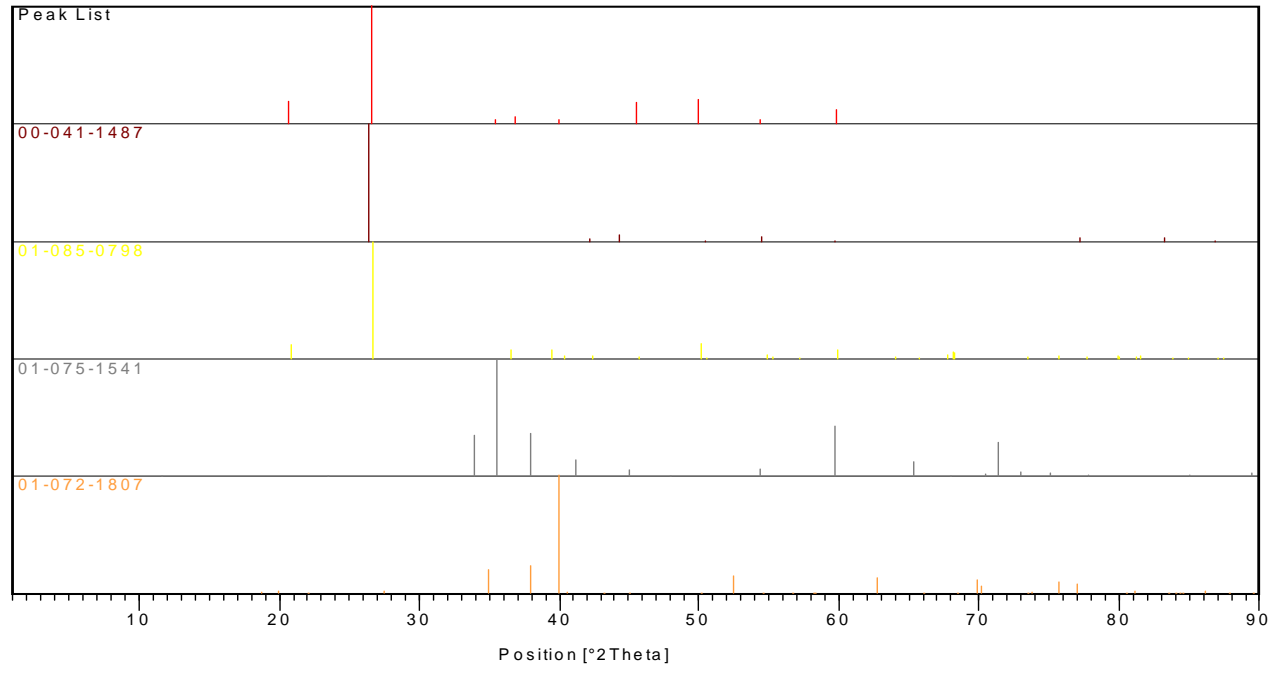

Figure 3: Plot of Identified Phases of the XRD 
From the result obtained it was observed that, the major diffraction peaks are $20.68^{\circ}$, $26.53^{\circ}, 35.41^{\circ}$ and $40.00^{\circ}$ and their inter-planar distance, $4.29 \AA, 3.36 \AA, 2.54 \AA$ and $2.26 \AA$, and their relative intensity of $\mathrm{X}$-ray scattering are $19.17,100.00,3.59$, and 3.26 and phases at these peaks as Quartz $\left(\mathrm{SiO}_{2}\right)$, Cliftonite:(C), Moissanite:( $\left.\mathrm{SiC}\right)$ and Titanium Oxide: $\left(\mathrm{Ti}_{6} \mathrm{O}\right)$, while each of these phases have a score of $30,31,19$ and 18 respectively (see Tables 2-3). The result shows that carbon has the highest percentage of all the compound and element present as revealed by the XRD analysis [5].

Table 1. Identified Patterns List of the XRD.

\begin{tabular}{lrrlrrl}
\hline Visible & Ref. Code & Score & $\begin{array}{c}\text { Compound } \\
\text { Name }\end{array}$ & $\begin{array}{c}\text { Displaceme } \\
\mathrm{nt}\left[{ }^{\circ} 2 \mathrm{Th} .\right]\end{array}$ & $\begin{array}{c}\text { Scale } \\
\text { Factor }\end{array}$ & $\begin{array}{c}\text { Chemical } \\
\text { Formula }\end{array}$ \\
\hline$*$ & $00-041-$ & 31 & Cliftonite & 0.000 & 0.657 & $\mathrm{C}$ \\
& $\begin{array}{r}1487 \\
*\end{array}$ & & & & & \\
& $01-085-$ & 30 & Quartz & 0.000 & 0.084 & $\mathrm{SiO}_{2}$ \\
$*$ & 0798 & & & & & \\
& $01-075-$ & 19 & Moissanite & 0.000 & 0.044 & $\mathrm{SiC}$ \\
$*$ & 1541 & & & & & \\
& $01-072-$ & 18 & Titanium & 0.000 & 0.045 & $\mathrm{Ti}_{6} \mathrm{O}$ \\
& 1807 & & Oxide & & & \\
\hline
\end{tabular}

Complete mineralogical analysis of bagasse ash carried out by X-Ray also revealed that the ash contains each of these elements $\mathrm{C}, \mathrm{O}, \mathrm{Si}, \mathrm{Ca}, \mathrm{Ti}, \mathrm{Al}, \mathrm{Fe}$ and $\mathrm{Zr}$ and none of these other elements H, Zn, Ga, Ge, As, Se, Br, Kr, Rb, Sr, Y, Nb, Mo, Tc, Ru, Rh, Pd, Ag, Cd, In, Sn, Sb, Te, I, Xe, Cs, Ba, La, Ce, Pr, Nd, Pm, Sm, Eu, Gd, Tb, Dy, Ho, Er, Tm, Yb, Lu, Hf, Ta are presented.

Morphologies of the bagasse ash by SEM with EDAX are show in Micrograph 1. The structure reveals that the size and shape of the particles vary; however, they can be sorted into three main groups - prismatic, spherical and fibrous [5].

The prismatic particles consist mainly of $\mathrm{Si}$ and $\mathrm{O}$. The spherical ones contain $\mathrm{Si}$ and $\mathrm{O}$ as well as $\mathrm{Ca}, \mathrm{Al}, \mathrm{Ti}$ and $\mathrm{Zr}$ with small amounts of $\mathrm{Fe}$. The fibrous on es consist of only $\mathrm{C}$ and $\mathrm{SiC}$ as a result of the EDAX scan in rectangle label A (see Micrograph 1). The results are consistent with XRD analysis of bagasse ash. Silica appears in prismatic particles or retained features of epidermal layer has been observed in other bagasse fly ash powders $[5,6]$. 
Table 2. Peak List of the XRD

\begin{tabular}{|c|c|c|c|c|c|c|}
\hline $\begin{array}{c}\text { Pos. } \\
{\left[{ }^{\circ} 2 \mathrm{Th} .\right]}\end{array}$ & $\begin{array}{l}\text { Height } \\
\text { [cts] }\end{array}$ & $\begin{array}{l}\text { FWHM } \\
\text { ['2Th.] }\end{array}$ & $\begin{array}{c}\text { d-spacing } \\
[\AA]]\end{array}$ & $\begin{array}{c}\text { Rel. Int. } \\
{[\%]}\end{array}$ & $\begin{array}{c}\text { Tip width } \\
\left.\text { [ }{ }^{\circ} 2 \mathrm{Th} .\right]\end{array}$ & $\begin{array}{c}\text { Matched } \\
\text { by }\end{array}$ \\
\hline 20.6783 & 170.60 & 0.2362 & 4.29552 & 19.17 & 0.2400 & $\begin{array}{r}01-085 \\
0798\end{array}$ \\
\hline 26.5272 & 890.09 & 0.1378 & 3.36021 & 100.00 & 0.1400 & $\begin{array}{r}00-041- \\
1487 ; 01- \\
085-0798\end{array}$ \\
\hline 35.4083 & 32.00 & 0.4723 & 2.53512 & 3.59 & 0.4800 & $\begin{array}{r}01-075- \\
1541\end{array}$ \\
\hline 36.8181 & 53.84 & 0.1181 & 2.44122 & 6.05 & 0.1200 & \\
\hline 39.9694 & 29.00 & 0.6298 & 2.25573 & 3.26 & 0.6400 & $\begin{array}{r}01-072- \\
1807\end{array}$ \\
\hline 45.5970 & 161.25 & 0.1181 & 1.98956 & 18.12 & 0.1200 & $\begin{array}{r}01-085- \\
0798\end{array}$ \\
\hline 50.0251 & 182.40 & 0.0960 & 1.82183 & 20.49 & 0.0800 & $\begin{array}{r}01-085- \\
0798 ; 01- \\
072-1807\end{array}$ \\
\hline 54.4399 & 31.76 & 0.2362 & 1.68545 & 3.57 & 0.2400 & $\begin{array}{r}00-041- \\
1487 ; 01- \\
075-1541 \\
01-072- \\
1807\end{array}$ \\
\hline 59.8377 & 105.46 & 0.1200 & 1.54439 & 11.85 & 0.1000 & $\begin{array}{r}00-041- \\
1487 ; 01- \\
085-0798 ; \\
01-075- \\
1541\end{array}$ \\
\hline
\end{tabular}




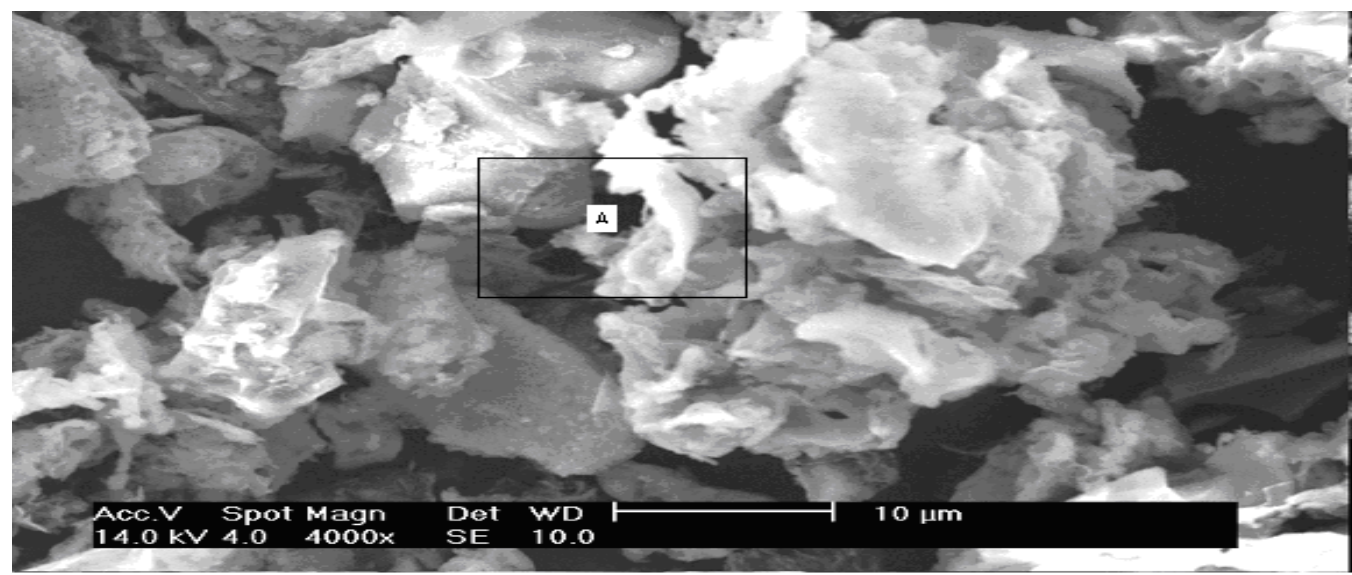

Micrograph 1: The structure of the bagasse ash as revealed by SEM/EDAX

The SEM result shows that both $\mathrm{SiO}_{2}$ and carbon have a fine structure, the latter having a finer one. This could be associated with pore size of $4.29 \AA$ (see Table 2) against carbon which has significant surface area in the range of hundreds of square meters per gram and microspores with pore size maxima around $3.36 \AA$ [5]. This is similar to bagasse ash obtained in other studies [4-6].

\subsection{Firing Shrinkage}

The firing shrinkage value of the bagasse ash is very low with a value is $0.85 \%$. This result confirm with the structure observed in the microstructure which is mainly carbon, silica and silicon carbide, since silica and graphite (C) expand during firing [9].

\subsection{Density}

Density of the sample is $1.95 \mathrm{~g} / \mathrm{cm}^{3}$ which means that bagasse ash is very light material. The value obtained fall within the range of density of carbon and silica which is 1.8 and $2.2 \mathrm{~g} / \mathrm{cm}^{3}$ respectively $[7,9,10]$.

\subsection{Refractoriness}

The sample was observed to have Seger Cone No. 23, with equivalent temperature of $1600^{\circ} \mathrm{C}$. This means bagasse ash can withstand operating temperature of $1600^{\circ} \mathrm{C}$ without load $[5,9$, and $11]$. 


\section{CONCLUSIONS}

From the analysis of the results given above, the followings conclusions can be made:

1) $\mathrm{XRD}$ analysis of the ash reveals Quartz:( $\left.\mathrm{SiO}_{2}\right)$, Cliftonite:(C), Moissanite:(SiC) and Titanium Oxide: $\left(\mathrm{Ti}_{6} \mathrm{O}\right)$ as the primary compounds

2) SEM/EDAX analysis reveals the presence of prismatic, spherical and fibrous structure, which also have similar compound with the XRD analysis.

3) The ash can withstand a temperature of up to $1600^{\circ} \mathrm{C}$ with a density of $1.95 \mathrm{~g} / \mathrm{cm}^{3}$

4) Based on the above properties, it is clear that presence of oxides and carbon in the ash will make it suitable for refectory and ceramic products such as insulation, membrane filters and structural ceramics. Also with fine particle size characteristics, implies that this bagasse ash can be used as facing sand moulding during casting operations.

\section{REFERENCES}

[1] Balogun S.:Potential of cassava liquid extract as a quenching medium for ferrous metal, M.Sc thesis, Dept. of Metallurgical and Material Engineering, Ahmadu Bello University, Zaria, Nigeria, 2009, pp 12-40.

[2] Magudu .I.A, Abdulwahab .M, Aigbodion V.S: Effect of iron fillings on the properties and microstructure of cast fiber-polyester/iron filings particulate composite Journal of Alloys and Compounds, 476 (2009) 807-811.

[3] Aigbodion.V.S, Hassan.S.B, Olajide.S,O, Agunsoye.O.J, AbdulRahaman.A.S. Okafor.G.E, The use of rice husk ash as an aggregate for foundry sand production in Nigeria, Proceedings of the Nigerian Metallurgical Society (NMS), (2008) Annual Conference \& Annual General Meeting, pp 16-22.

[4] Payá JJ, Monzó,.J , Borrachero .M V, Díaz-Pinzón .L, Ordóñez .L M: Sugar-cane Bagasse ash (SCBA): studies on its properties for reusing in concrete production Journal of Chemical Technology \& Biotechnology , 2007, Volume 77 Issue 3, pp. 21 - 32.

[5] Aigbodion.V.S: Potential of using bagasse ash particle in Metal Matrix Composite, $\mathrm{PhD}$ work on-going, Department of Metallurgical and Materials Engineering, Ahmadu Bello University, Samaru, Zaria, Nigeria, 2008

[6] Barroso J, Barreras F, Amaveda H, Lozano A: On the optimization of boiler efficiency using bagasse as fuel. Fuel 2003;82:1451-63

[7] Osinubi.K.J and Alhassan.M: Bagasse ash modification of Shika laterite, Nigerian Journal of Engineering, 2007, Vol 14, No Pp96-74104

[8] Aigbodion V.S and Asuke,F: Effect of Kankara clay on some refractory properties of Igbokoda silica sand "Inter-Research Journal on Engr. Sci and Tech. 2007, vol.4, No.2, 66-73.

[9] Hassan, S.B: Modern Refractories: Production, Properties, Testing and Applications, 2005, pp 23-25

[10] Kevorkijan V: American Ceramic Society Bulletin, 2003, Vol. 82, p60. 
[11] Chesti, A.R, .Refractories Manufacture, Properties and Application. Prentice Hall of private limited, London, 1986, 1-140. 